\title{
The Evaluation of the Effect of Cranioplasty on Cerebral Metabolism Using F-18 FDG PET/CT
}

\section{Dekompresyon Amacıyla Yapılan Kraniyektomi Sonrası Kemik Defektlerinin Kraniyoplasti ile Kapatılmasının Beyin Metabolizması Üzerine Etkisinin F-18 FDG PET/BT ile Değerlendirilmesi}

\author{
(D) Mehmet Yaman¹, (D) Cihan Gündoğan², (D) Mustafa Yavuz Samanci ${ }^{1}$, (D) Esra Arslan², (D) Veysel Antar \\ 1 University of Health Sciences, İstanbul Health Research and Application Center, Clinic of Neurosurgery, İstanbul, Turkey \\ 2University of Health Sciences, İstanbul Health Research and Application Center, Clinic of Nuclear Medicine, i̇stanbul, Turkey
}

\begin{abstract}
Introduction: Decompressive craniectomy (DC) is commonly used as the treatment for refractory intracranial hypertension. The indications for cranioplasty after DC are cosmetic repair and, mainly, restoration of cerebral protection. Unexpected improvement in patient's neurological status has been observed among patients that underwent cranioplasty. This study was conducted to determine the impact of cranioplasty on cerebral metabolism and its correlation with clinical outcome.
\end{abstract}

Methods: Twelve patients who underwent DC for various reasons underwent positron emission tomography/computed tomography (PET/CT) with F-18 labeled fluorodeoxyglucose (FDG) before and after cranioplasty.

Results: There were 11 (92\%) male patients and 1 (8\%) female patient in the study. The mean age was $46.8 \pm 14.1$ years. The most common indication was trauma (58\%), while the most frequently affected side was right (67\%). The cerebral metabolism evaluated by FDG-PET/CT was found to be significantly decreased in the hemisphere ipsilateral to the trauma compared with the contralateral hemisphere (3.87 vs 2.72, $p=0.012$ ). All patients showed improvement in one or more anatomic areas with cranioplasty (median: 6, minimum: 3 , maximum: 8). Cranioplasty did not cause a significant change in FDG uptake in both hemispheres (ipsilateral $p=0.814$, contralateral $p=0.308$ ). Nevertheless, a general improvement and decrease in symptoms were observed in all patients before and after cranioplasty.

Conclusion: Though we are unable to demonstrate a significant increase in the cerebral metabolism, cranioplasty was observed to have a therapeutic role in terms of clinical outcome improvement.

Keywords: Cerebral metabolism, cranioplasty, decompressive craniectomy öz

Amaç: Dekompresif kraniyektomi (DK), dirençli intrakraniyal hipertansiyon tedavisinde sıkıkla kullanılmaktadır. DK sonrası kraniyoplasti endikasyonları kozmetiktir ve temel olarak serebral dokunun korunması amaçlanır. Kraniyoplasti yapılan hastalarda, hastaların nörolojik durumunda beklenmedik iyileşmeler gözlenmiştir. Bu çalışma, kraniyoplastinin beyin metabolizmasına olan etkisini ve bunun klinik sonuç ile korelasyonunu belirlemek için yapıldı.

Yöntemler: Kliniğimizde çeșitli sebepler ile DK yapılan on iki hastaya kraniyoplasti öncesi ve sonrası 18-F işaretli florodeoksiglukoz (FDG) ile pozitron emisyon tomografisi/ bilgisayarlı tomografi (PET/BT) çekimi yapıldı.

Bulgular: Çalışmada 11 (\%92) erkek ve 1 (\%8) kadın hasta vardı. Ortalama yaş 46,8 $\pm 14,1$ yıldı. En sık endikasyon travma (\%58) iken, en sık etkilenen taraf sağ (\%67) idi. FDG-PET/BT ile değerlendirilen serebral metabolizmanın, travma ile aynı taraftaki hemisferde karșı taraf hemisfer ile karșılaștırıldığında anlamlı olarak azalmış olduğu saptandı (3,87 vs 2,72, $p=0,012$ ). Tüm hastalarda kraniyoplasti ile 1 veya daha fazla anatomik bölgede düzelme gözlendi (medyan: 6, minimum: 3, maksimum: 8). Kraniyoplasti her iki hemisferde FDG alımında anlamlı bir değișikliğe sebep olmamıștır (ipsilateral $p=0,814$, kontralateral $p=0,308$ ). Buna rağmen, hastaların kraniyoplasti öncesi ve sonrası nörolojik durumları arasında tüm hastalarda genel bir iyileșme ve semptomlarda azalma tespit edildi.

Sonuç: Serebral metabolizmada belirgin bir artış gösteremesekte, kraniyoplastinin klinik sonuçlarda iyileşme açısından terapötik bir rolü olduğu gözlendi.

Anahtar Kelimeler: Serebral metabolizma, kraniyoplasti, dekompresif kraniyektomi

Address for Correspondence/Yazıșma Adresi: Mustafa Yavuz Samancı MD, University of Health Sciences, İstanbul 


\section{Introduction}

Brain edema may develop after traumatic brain injury (TBI), ischemic stroke, and many other conditions affecting the brain $(1,2)$. Increased brain edema leads to increased intracranial pressure, due to the fact that the skull is stiff and does not have the possibility of expansion, which leads to a decrease in cerebral perfusion pressure, cerebral blood flow and oxygenation. These effects can lead to brain herniation and death if not treated.

Decompressive craniectomy (DC), which is the removal of a part of the skull, is a treatment option to prevent tissue damage due to brain edema. It was described by Kocher in 1901 and Harvey Cushing reported a reduction in surgical mortality from $50 \%$ to $15 \%$ with DC in 1908 (3). Despite the reduced morbidity and mortality associated with this surgical technique, early and late onset complications can be seen in many patients (4-7). Patients with large skull defects are at risk for trephine syndrome (TS), characterized by headache, dizziness, behavior and mood changes, seizures, fatigue, motor deficits and language disorders $(8,9)$.

Following DC, cranioplasty was previously considered to be useful in terms of protection and cosmetic. However, unexpected improvements were observed in the neurological status of patients in many centers (10-12). Although the mechanism of action of cranioplasty is not known, it is thought to neutralize the possible pathophysiological mechanisms (abnormal brain pulsatility, changes in cerebrospinal fluid (CSF) and venous drainage dynamics, changes in blood flow and metabolism) by normalizing atmospheric pressure (13). Good results are thought to be due to improved collateral circulation, decreased tissue edema, oxygenation in damaged tissues and improvement in energy metabolism $(10,14,15)$.

This prospective study was designed to investigate the effect of cranioplasty on cerebral metabolism using positron emission tomography/computed tomography (PET/CT) with F-18 labeled fluorodeoxyglucose (FDG) as an indication of functional recovery.

\section{Methods}

This prospective observational study was performed by İstanbul Health Research and Application Center, University of Health Sciences, Department of Neurosurgery and Department of Nuclear Medicine. Following approval of the ethics committee of our hospital (decision number: 826, decision date: 02.09.2016), 13 patients who underwent DC and who were admitted to our clinic for cranioplasty between January 2016 and February 2017 were included in this study. Patients were included in the study after signing informed consent form. Of the 13 patients, one patient was excluded from the study due to missing followup. Routine CT scans were performed preoperatively and postoperatively in all patients.

\section{Positron Emission Tomography/Computed Tomography Imaging Protocol}

PET/CT imaging of the patients included in the study was performed by Biograph mCT 20 Excel LSO FDG-PET/CT scanner (Siemens Molecular Imaging, Hoffmann Estates, IL, USA). After at least six hours of fasting,
3.7-5.2 MBq/kg F-18 FDG was administered intravenously when the serum glucose level was below $140 \mathrm{mg} / \mathrm{dL}$. The cranial region was visualized 50-70 minutes after injection.

CT imaging for PET/CT imaging was performed by a 20-slice multidetector CT scanner with 80-140 kV, 20-666 mAs (It is determined automatically according to the patient and the region examined by the manufacturer's software (CareDose 4D) with personalized automatic exposure control system), 0.8 pitch and 512x512 matrix. CT scan was performed in a craniocaudal direction with a cross-sectional thickness of $5 \mathrm{~mm}$ and a rotation time of $0.5 \mathrm{sec}$, followed by a PET scan of 1.5 - $\mathrm{min}$ acquisition time per bed position. PET parameters were as follows: PET crystal material: LSO, crystal size: 4×4×20 mm, crystal number: 24.336 , crystal ring number: 39 , ring diameter: $84.2 \mathrm{~cm}$, resolution: $4.2 \mathrm{~mm}$, gantry opening: 70 and $78 \mathrm{~cm}$, detector pixelar transverse field of view (FOV): $70 \mathrm{~cm}$, and axial FOV: $16.2 \mathrm{~cm}$. Ultra HD images were obtained using the time of flight + True $X$ algorithm for reconstruction.

\section{Evaluation of Positron Emission Tomography/Computed Tomography Images}

The images of all patients were evaluated together by two nuclear medicine experts who had 3 and 5 years experience in the field of PET/CT. The images were analyzed at Syngo.via Workstation (SyngoMI, Siemens). In addition to visual evaluation, PET axial section images were evaluated using a three-dimensional stereotactic surface projection software (3D-SSP; 3D Stereotactic Surface Projection) or NEUROSTAT (University of Utah, Department of Radiology and Imaging Sciences, Salt Lake City, UT, USA) software. This program resizes the brain images of the patient according to a standard template and makes a rotation correction, and compares voxel counts in each image unit placed according to Talairach coordinates with a normal database of suitable age (19-30, 31-54, 5591 age ranges). It then provides the regional deviations in the patient (z-score) as standard deviation (SD) and reflects on the brain template in 8 different projections (right lateral, left lateral, superior, inferior, anterior, posterior, right medial, left medial) by converting values to numerical and color scale. FDG-PET/CT images before and after surgery were re-evaluated with the NEUROSTAT program, and SD (z-score) values were obtained by comparing the data of the patients with the normal means of their age group.

\section{Statistical Analysis}

Mean, SD, median, minimum, maximum, frequency and ratio values were used in descriptive statistics of the data. Kolmogorov-Smirnov test was used to analyze the normal distribution. ANOVA (Tukey test), independent sample $t$ test, Kruskal-Wallis, Mann-Whitney-U test were used to analyze the quantitative independent data. Wilcoxon test was used to analyze the dependent quantitative data. SPSS 22.0 for Windows 10 (IBM Corporation Armonk, NY, USA) was used in the analysis.

\section{Results}

The differences between demographics, surgical characteristics and clinical symptoms of patients before and after cranioplasty are presented in Table 1. There were 11 (92\%) male patients and one (8\%) female patient. The mean age was $46.8 \pm 14.1$ years. The most common 
indication was trauma (58\%), while the most frequently affected side was right (67\%). The median time between craniectomy and cranioplasty was 16 weeks (range 6-936 weeks). Autologous bone graft was placed in 10 patients and synthetic bone graft was used in two patients. The differences between the neurological status of the patients before and after cranioplasty were done by routine clinical evaluation, not by specific tests, and overall functional and cognitive improvement was observed in all patients after cranioplasty.

The cerebral metabolism assessed by FDG-PET/CT was found to be significantly decreased in the hemisphere ipsilateral to trauma compared to the contralateral hemisphere (3.87 vs 2.72, $p=0.012$ ) (Figure 1). Improvement was observed in one or more regions with cranioplasty in all patients (median: 6, minimum: 3, maximum: 8). The most significant improvement was seen in the right parietal $(n=8)$, right caudate $(n=8)$ and left caudate $(n=8)$ regions (Figure 2). Cranioplasty did not cause a significant change in FDG uptake in both hemispheres (ipsilateral $p=0.814$, contralateral $p=0.308$ ). There were no statistically significant differences between the values of other regions before and after cranioplasty. In spite of this, a general improvement and decrease in symptoms were observed in all patients.

\section{Table 1. Demographic and surgical characteristics}

\begin{tabular}{|c|c|c|c|c|c|c|c|}
\hline Patient & Age (years) & Gender & Indications & Side & Timing & $\begin{array}{l}\text { Cranioplasty } \\
\text { material }\end{array}$ & Pre-op/Post-op neurological condition \\
\hline 1 & 61 & Male & Hemorrhagic stroke & Left & $20 w k$. & Autograft & $\begin{array}{l}\text { Improvement in headache, tinnitus, dizziness } \\
\text { with head movements, speech difficulties }\end{array}$ \\
\hline 2 & 54 & Male & Trauma & Right & 16 wk. & Autograft & Significant improvement in left leg function \\
\hline 3 & 22 & Male & Trauma & Left & $18 \mathrm{yrs}$. & Synthetic & $\begin{array}{l}\text { Progressive improvement in both cognitive and } \\
\text { motor functions }\end{array}$ \\
\hline 4 & 65 & Male & Hemorrhagic stroke & Right & 8 wk. & Autograft & Improvement in headache and irritability \\
\hline 5 & 53 & Male & Trauma & Right & 60 wk. & Synthetic & A partial improvement in left hemiparesis \\
\hline 6 & 61 & Male & Hemorrhagic stroke & Right & $6 w k$. & Autograft & $\begin{array}{l}\text { Improvement in severe depressive mood with } \\
\text { anhedonia, irritability and sleep changes }\end{array}$ \\
\hline 7 & 44 & Male & Trauma & Left & $28 w k$. & Autograft & Improvement in functional use of right hand \\
\hline 8 & 46 & Male & Trauma & Right & 12 wk. & Autograft & Improvement in speech difficulties \\
\hline 9 & 35 & Male & Hemorrhagic stroke & Right & $48 w k$. & Autograft & $\begin{array}{l}\text { Spastic left hemiparesis, but can walk without } \\
\text { help and simple movements in the left upper } \\
\text { extremity }\end{array}$ \\
\hline 10 & 23 & Male & Trauma & Right & 12 wk. & Autograft & $\begin{array}{l}\text { Significant improvement in balance, and place } \\
\text { and time orientation, becoming independent in } \\
\text { some daily activities }\end{array}$ \\
\hline 11 & 52 & Female & Hemorrhagic stroke & Right & 16 wk. & Autograft & $\begin{array}{l}\text { Improvement of muscle strength in the left lower } \\
\text { extremity }\end{array}$ \\
\hline 12 & 46 & Male & Trauma & Left & 16 wk. & Autograft & $\begin{array}{l}\text { Better performance in memory tasks, } \\
\text { improvement in hand skills in the right upper } \\
\text { extremity }\end{array}$ \\
\hline
\end{tabular}
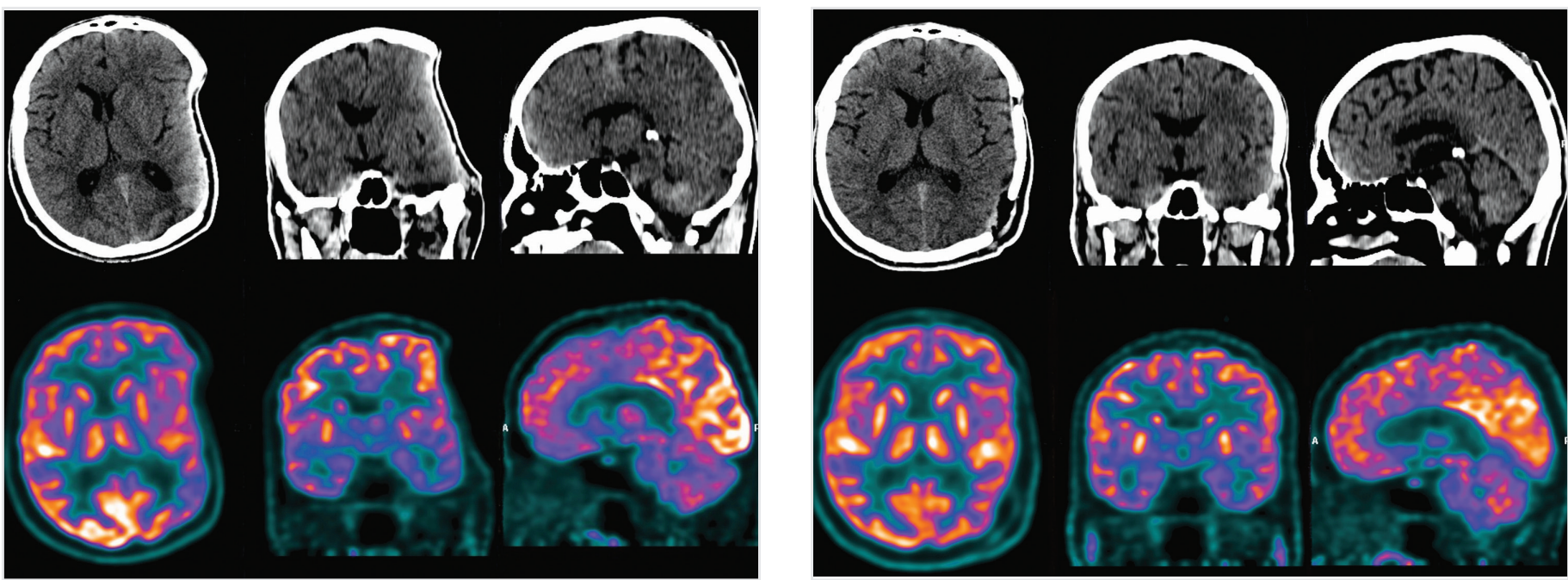

Figure 1. Axial, coronal and sagittal computed tomography and positron emission tomography images showing hypometabolism in the left parietotemporal cortex and basal ganglia compared to right in a 46-yearold male patient before cranioplasty

Figure 2. A significant improvement in the metabolism in the left parietotemporal cortex and basal ganglia observed in post-cranioplasty $3^{\text {rd }}$ month computed tomography and positron emission tomography scan of the patient mentioned in Figure 1 


\section{Discussion}

DC has been widely used for the treatment of intracranial hypertension resistant to drug therapy and has succeeded in effectively reducing intracranial hypertension in $85 \%$ of such patients. Good clinical results were obtained in $40 \%$ of patients in the long term (16). In the past, the majority of patients after DC underwent cranioplasty for cosmetic or protective reasons, and studies have shown that cranioplasty has a positive effect on normal CSF and blood flow dynamics. A number of studies, the oldest being in 1977, have been published reporting improved clinical status after cranioplasty $(10,17,18)$. In our prospective study, we aimed to evaluate clinical outcome and cerebral metabolism after cranioplasty. Unlike other studies, hemorrhagic stroke patients were included in our study in addition to TBI and we aimed to show the positive effect of cranioplasty in these patients.

After DC, a sunken skin is observed above the bone defect and various neurological symptoms, such as neu rological deficit, headache, dizziness, fatigue, and psychiatric changes, have been attributed to this condition, namely TS or Sinking Skin Flap Syndrome $(8,19)$. The pathophysiology of this syndrome has been suggested to include many factors such as cerebral blood flow, CSF and atmospheric pressure (18,20). Among these factors, it has been reported that atmospheric pressure causes compression and cortical tissue damage on the unprotected brain tissue in the bone defect area as a main factor, leading neurological deficits, and that neurological improvement is achieved with the disappearance of this condition after cranioplasty (20). In a study by Segal et al. (11), it was claimed that atmospheric pressure changed cerebral hemodynamics and inhibited cerebral blood flow, and cerebral perfusion increase after cranioplasty was shown in subsequent studies (10,17,21-23).

Imaging with cranial F-18 FDG-PET/CT is useful in evaluating regional cerebral metabolism. Following brain damage, glucose metabolism is affected as a result of ionic alterations and neurochemical cascades. F-18-FDG-6-Phosphatase is a good marker for the in vivo distribution of glucose uptake by cells. FDG-PET/CT was evaluated in previous studies in both TBI $(24,25)$ and stroke $(26,27)$ patients, and correlations between cognitive and behavioral disorders and decreased cortical metabolism were demonstrated. In our patients, it was found that glucose metabolism was significantly decreased in the hemisphere ipsilateral to trauma compared to the contralateral hemisphere. An increase in glucose metabolism after cranioplasty was seen in one or more regions, but unlike other studies, no statistically significant differences were found between the values. However, similar to other studies, neurological improvement of varying degree was observed in all patients after cranioplasty. The discrepancy between the change in glucose metabolism over time and the neurological improvement in our study may be explained by the fact that our patient group is composed of patients of different ages, patients having different injury mechanisms and severities, different timing of cranioplasty, different cranioplasty materials and PET timing. The reason for this is the time and resource limitation of patient selection in our study. In addition, independent of our patient group, use of drugs that suppress brain metabolism and neurological recovery such as benzodiazepines and anticonvulsants $(28,29)$ and transient hyperglycemia attacks $(30)$ which can be seen in all patients with brain damage may have affected our results.

\section{Conclusion}

DC affects cortical perfusion and clinical outcome. In our study, F-18 FDG-PET/CT showed a decrease in glucose metabolism in hemisphere ipsilateral to brain damage. Considering the complex nature of brain injury, it should be considered that the improvement in cerebral metabolism and the degree of neurological recovery might be multifactorial. However, this preliminary study is the first metabolic imaging study. We believe that F-18 FDG-PET/CT may have a potential to contribute to a better understanding of metabolic changes that may occur in the brain after DC and in other regions with studies including larger patient series.

Ethics Committee Approval: This prospective observational study was performed by İstanbul Health Research and Application Center, University of Health Sciences, Department of Neurosurgery and Department of Nuclear Medicine. Following approval of the ethics committee of our hospital (decision number: 826, decision date: 02.09.2016).

Informed Consent: Patients were included in the study after signing informed consent form.

Peer-review: Internally peer-reviewed.

Author Contributions: Concept - M.Y., C.G., M.Y.S., E.A., V.A.; Design M.Y., C.G., M.Y.S., E.A., V.A.; Supervision - A M.Y., C.G., M.Y.S.; Resources - M.Y., C.G., M.Y.S., E.A.; Materials - M.Y., M.Y.S., V.A.; Data Collection and/ or Processing - M.Y., C.G., M.Y.S., E.A., V.A.; Analysis and/or Interpretation - M.Y., C.G., M.Y.S., E.A.; Literature Search - M.Y., C.G., M.Y.S.; Writing Manuscript - M.Y., C.G., M.Y.S., E.A.; Critical Review - M.Y., C.G., M.Y.S.

Conflict of Interest: No conflict of interest was declared by the authors.

Financial Disclosure: The authors declared that this study received no financial support.

\section{References}

1. Unterberg AW, Stover J, Kress B, Kiening KL. Edema and brain trauma. Neuroscience 2004; 129: 1021-9.

2. Katzman R, Clasen R, Klatzo I, Meyer JS, Pappius HM, Waltz AG. Report of joint committee for stroke resources. IV. Brain edema in stroke. Stroke 1977; 8: $512-40$.

3. Cushing H. I. Subtemporal decompressive operations for the intracranial complications associated with bursting fractures of the skull. Ann Surg 1908; 47: 641-4.

4. Honeybul S. Complications of decompressive craniectomy for head injury. J Clin Neurosci 2010; 17: 430-5.

5. Stiver SI. Complications of decompressive craniectomy for traumatic brain injury. Neurosurg Focus 2009; $26: 7$.

6. Yang XJ, Hong GL, Su SB, Yang SY. Complications induced by decompressive craniectomies after traumatic brain injury. Chin J Traumatol 2003; 6: 99-103.

7. Flint AC, Manley GT, Gean AD, Hemphill JC 3rd, Rosenthal G. Post-operative expansion of hemorrhagic contusions after unilateral decompressive hemicraniectomy in severe traumatic brain injury. J Neurotrauma 2008; 25: 503-12.

8. Yamaura A, Makino H. Neurological deficits in the presence of the sinking skin flap following decompressive craniectomy. Neurol Med Chir (Tokyo) 1977; 17: $43-53$.

9. Stiver SI, Wintermark M, Manley GT. Motor trephine syndrome: a mechanistic hypothesis. Acta neurochir Suppl 2008; 102: 273-7. 
10. Suzuki N, Suzuki S, Iwabuchi T. Neurological improvement after cranioplasty. Analysis by dynamic CT scan. Acta Neurochir (Wien) 1993; 122: 49-53.

11. Segal DH, Oppenheim JS, Murovic JA. Neurological recovery after cranioplasty. Neurosurgery 1994; 34: 729-31. 7

12. Kuo JR, Wang CC, Chio CC, Cheng TJ. Neurological improvement after cranioplasty - analysis by transcranial doppler ultrasonography. J Clin Neurosci 2004; 11: 486-9.

13. Wee HY, Kuo JR. Never neglect the atmospheric pressure effect on a brain with a skull defect. Int Med Case Rep J 2014; 7: 67-9.

14. Winkler PA, Stummer W, Linke R, Krishnan KG, Tatsch K. Influence of cranioplasty on postural blood flow regulation, cerebrovascular reserve capacity, and cerebral glucose metabolism. J Neurosurg 2000; 93: 53-61.

15. Richaud J, Boetto S, Guell A, Lazorthes Y. Effects of cranioplasty on neurological function and cerebral blood flow. Neurochirurgie 1985; 31: 183-8.

16. Morgalla $\mathrm{MH}$, Will BE, Roser F, Tatagiba M. Do long-term results justify decompressive craniectomy after severe traumatic brain injury? J Neurosurg 2008; 109: 685-90.

17. Chibbaro S, Vallee F, Beccaria K, Poczos P, Makiese O, Fricia M, et al. The impact of early cranioplasty on cerebral blood flow and its correlation with neurological and cognitive outcome. Prospective multi-centre study on 24 patients. Rev Neurol (Paris) 2013; 169: 240-8

18. Yamaura A, Sato M, Meguro K, Nakamura T, Uemura K. Cranioplasty following decompressive craniectomy-analysis of 300 cases (author's transl). No Shinkei Geka 1977; 5: 345-53.

19. Dujovny M, Aviles A, Agner C, Fernandez P, Charbel FT. Cranioplasty: cosmetic or therapeutic? Surg Neurol 1997; 47: 238-41.

20. Stula D. The problem of the "sinking skin-flap syndrome" in cranioplasty. J Maxillofac Surg 1982; 10: 142-5.
21. Yoshida K, Furuse M, Izawa A, lizima N, Kuchiwaki H, Inao S. Dynamics of cerebral blood flow and metabolism in patients with cranioplasty as evaluated by 133Xe CT and 31P magnetic resonance spectroscopy. J Neurol Neurosurg Psychiatry 1996; 61: 166-71.

22. Sakamoto S, Eguchi K, Kiura Y, Arita K, Kurisu K. CT perfusion imaging in the syndrome of the sinking skin flap before and after cranioplasty. Clin Neurol Neurosurg 2006; 108: 583-5

23. Mah JK, Kass RA. The impact of cranioplasty on cerebral blood flow and its correlation with clinical outcome in patients underwent decompressive craniectomy. Asian J Neurosurg 2016;11:15-21.

24. Bergsneider M, Hovda DA, Shalmon E, Kelly DF, Vespa PM, Martin NA, et al. Cerebral hyperglycolysis following severe traumatic brain injury in humans: a positron emission tomography study. J Neurosurg 1997; 86: 241-51.

25. Langfitt TW, Obrist WD, Alavi A, Grossman RI, Zimmerman R, Jaggi J, et al. Computerized tomography, magnetic resonance imaging, and positron emission tomography in the study of brain trauma. Preliminary observations. J Neurosurg 1986; 64: 760-7.

26. Nasu S, Hata T, Nakajima T, Suzuki Y. Evaluation of 18F-FDG PET in acute ischemic stroke: assessment of hyper accumulation around the lesion. Kaku Igaku 2002; 39: 103-10.

27. Kuhl DE, Phelps ME, Kowell AP, Metter EJ, Selin C, Winter J. Effects of stroke on local cerebral metabolism and perfusion: mapping by emission computed tomography of 18FDG and 13NH3. Ann Neurol 1980; 8: 47-60.

28. Schallert T, Hernandez TD, Barth TM. Recovery of function after brain damage: severe and chronic disruption by diazepam. Brain Res 1986; 379: 104-11.

29. Hernandez TD, Holling LC. Disruption of behavioral recovery by the anticonvulsant phenobarbital. Brain Res 1994; 635: 300-6.

30. Melamed E. Reactive hyperglycaemia in patients with acute stroke. J Neurol Sci 1976; 29: 267-75. 